\title{
IDENTIFICATION AND PARTIAL CHARACTERIZATION OF CRUDE EXTRACELLULAR ENZYMES FROM BACTERIA ISOLATED FROM SHRIMP WASTE PROCESSING
}

\author{
Identifikasi dan Karakterisasi Parsial Enzim Kasar Ekstraseluler \\ dari Bakteri yang Diisolasi dari Pengolahan Limbah Udang
}

\author{
Ekowati Chasanah'1), Mahrus Ali'2), and Miftahul IImi ${ }^{31}$ \\ 1)Research and Development Center for Marine and Fisheries Product Processing and Biotechnology \\ ${ }^{2)}$ Dept. of Fisheries Faculty of Agriculture, University of Lampung; ${ }^{3)}$ Faculty of Biology, Gadjah Mada University, Yogyakarta \\ *Correspondence Author: Ekowati Chasanah, KS.Tubun Petamburan VI Jakarta Pusat 10260, E-mail: ekowatichasanah@gmail.com
}

\begin{abstract}
Attention on chitin degrading enzymes has been growing since their ability to reduce the waste of shrimp/other crustaceans processing industries and converting them into value added products such as biologically active chitin and chitosan oligomer. Previous experiment found that KLU 11.16 isolate was one of the potential bacteria isolated from shrimp waste producing chitinolytic enzymes including chitosanases. A study on the identification of KLU 11.16 extracellular crude enzyme was carried out by cultivating the bacteria on chitin medium. Due to the wide application of chitosanase, the characterization of the crude chitosanase was carried out after an identification of the enzymes secreted. Based on assessment using zymogram technique, this bacteria secreted a mixed extracellular chitinolytic enzyme and other hydrolytic enzyme. The crude chitinolytic enzyme degraded $85 \%$ deacetylated (DA) better than $100 \%$ DA chitosan, and slightly degraded glycol chitin, indicating that KLU 11.16 secreted chitosanases and chitinases enzyme. In addition to the chitinolytic enzyme, the bacteria also secreted protein and carbohydrate degrading enzymes when running at SDS-PAGE enriched with casein, soluble starch and CMC substrates. Crude chitosanases enzyme was performed well at $\mathrm{pH} 6$ and temperature of $30^{\circ} \mathrm{C}$, and the activity can be increased by addition of $1 \mathrm{mM} \mathrm{Fe}^{2+}$ in form of chloride salt. Addition of detergent, i.e $1 \mathrm{mM}$ of Triton X-100 and SDS slightly decreased the activity. Future application of the crude chitosanase from KLU 11.16 was on producing chitosan derivative such as chitosan oligomer using substrate of $85 \%$ DA chitosan, which is more digestable by other enzymes secreted by KLU 11.16
\end{abstract}

Keywords: extracellular enzyme, KLU 11.16, identification

\begin{abstract}
ABSTRAK
Perhatian terhadap enzim pendegradasi kitin semakin berkembang sejak diketahui bahwa enzim ini mampu mengubah limbah pengolahan udang dan krustase lain menjadi produk yang memiliki nilai tambah yang besar seperti oligomer kitin dan kitosan yang memiliki aktivitas biologi. Riset terdahulu mendapatkan isolat KLU 11.16, yang diisolasi dari limbah udang, sebagai salah satu isolat yang berpotensi memproduksi enzim pendegradasi kitin (kitinolitik), termasuk enzim kitosanase. Penelitian tentang identifikasi enzim kasar yang disekresi oleh KLU 11.16 telah dilakukan dengan mengkultivasi isolat bakteri tersebut di medium kitin. Selanjutnya, karakterisasi hanya dilakukan terhadap kitosanase dari enzim kasar yang disekresi tersebut mengingat luasnya aplikasi kitosanase. Dengan menggunakan teknik zimogram, hasil menunjukkan bahwa isolat bakteri ini mensekresikan campuran enzim ekstraseluler pendegradasi kitin dan hidrolitik lain. Enzim kasar kitinolitik pendegradasi kitin dapat menghidrolisis $85 \%$ terdeasetilasi (DA) $85 \%$ kitosan lebih baik dari pada kitosan DA 100\%, dan sedikit menghidrolisis glikol kitosan, mengindikasikan bahwa KLU 11.16 mensekresikan kitosanase dan kitinase. Selain enzim kitinolitik, bakteri tersebut juga mensekresikan enzim pendegradasi protein dan karbohidrat. Kitosanase yang ada dalam campuran enzim kasar tersebut beraktivitas secara baik pada $\mathrm{pH} 6$ dan suhu $30^{\circ} \mathrm{C}$, dan akan meningkat aktivitasnya apabila ditambah dengan $1 \mathrm{mM} \mathrm{Fe} \mathrm{F}^{2+}$ dalam bentuk garam klorida. Penambahan detergen Triton X-100 dan SDS sebesar $1 \mathrm{mM}$ sedikit mengurangi aktivitas enzim. Aplikasi kedepan enzim kasar kitosanase dari KLU 11.16 ini adalah untuk memproduksi oligomer kitosan dengan menggunakan substrat kitosan DA $85 \%$, yang lebih mampu dihidrolisis oleh enzim-enzim yang disekresi oleh KLU 11.16.
\end{abstract}

Kata Kunci: enzim ekstraseluler, KLU 11.16, identifikasi 


\section{INTRODUCTION}

Chtin is the second most abundant polymer in the world after cellulose, and marine is considered the biggest sources of chitin. The presence of chitin degrading microbes in marine environment is hence very important and abundance in quantity due to the nature of a recycling process in marine. One of chitin sources is shrimp exosceleton; therefore, shrimp processing waste is one of potential sources for chitin and chitosan biopolymer as well as microbes producing chitinolytic enzymes. Indonesia, as marine country, produce relatively huge shrimp and crustacean exoskeleton. The potency of shrimp and crustacean waste in Indonesia was estimated $\pm 76,657$ $-114,986$ MT of shrimp shell and 3,643 - 4,128 MT of crab shell equals to $12,045-17,867 \mathrm{MT}$ a year chitin (Fawzya \& Wibowo, 2009).

The management of this waste needs special attention due to this huge quantity and the high pollutable potentials of the wastes, otherwise it could raise an environmental problem. Developing the waste into valuable product such as chitin and chitosan oligomers are not only solving the environmental problem but also generating added value products.

Production of microbial chitinolytic enzyme have received increasing attention in recent years due to its potential application in various fields. Chitinolytic enzymes are a group of chitin degrading enzymes including chitinases and chitosanases. Chitinase hydrolyze chitin polymer into its monomer form of chitin, i.e. 2-acetamido-2-deoxy- $\beta$-D-glucose ( $\mathrm{N}$ acetylglucosamine), while chitosanase hydrolyze chitosan into its monomer $\mathrm{N}$-glucosamine (Patil et al. 2000; Charles -Rodriguez et al., 2008). Based on the capability to split $\beta$ 1-4 glycosidic linkage, chitosanases can be grouped into 3 classes (Fukamizo \& Brezinski, 1997) that can be tested using various deacetylated (DA) chitosan as substrate. Chitosanase is defined by IUB-MB as an enzyme that are capable of hydrolysing $\beta$ 1-4 glycosidic linkage of commercial chitosan which have $30-60 \%$ acetyl groups (Tremblay et al., 2001), while chitinase, lysozyme and celulase enzyme are also capable of hydrolysing commercial chitosan with $20-35 \%$ acetyl groups. However, unlike chitinase, chitosanase is capable of hydrolysing $\beta 1-4$ glycosidic linkage in $100 \%$ DA chitosan. Therefore, the specifity of substrate experiment was important in defining the major chitinolytic degrading enzyme presented in this crude enzyme.

Chitinolytic enzymes have been used as biocontrol agent of fungi and insect (Chien-Jui et al., 2005), production of oligosaccharides and chloroplast yeast cell dan single cell protein from yeast (Patil et al.
2000; Sørbotten et al., 2005). As biocontrol, fungal plant diseases are the important target since fungal plant disease is one of the major concerns of agricultural food production worldwide. Chitinolytic enzymes produced by microorganism have ability to degrade the fungal cell wall, therefore, the enzyme is very important in biotechnology technique such as protoplast preparation.

Exploration of chitinolytic enzyme from fisheries product and marine environment has been carried out from shrimp paste terasi (Zilda et al., 2006; Noviendri et al., 2006), as well as from shrimp waste (Chasanah et al., 2009; Chasanah et al., 2011) and biota such as sponges (Uria et al., 2005). Our previous study reported on 106 isolates isolated from shrimp waste processing, and one of them, Acinetobacter sp KPU 218, produced extracellular chitinase enzyme (Chasanah et al., 2009). One of other potential bacteria isolates from the shrimp waste is KLU 11.16, and previous study on the application of the crude enzyme to produce chitooligosaccharide showed that the bioactivity of the chitooligosaccharide produced by the crude enzymes showed very good antimicrobial activity (Chasanah et al., 2009). Information on all these enzymes secreted is very important since it will affect on the further application of the crude enzymes. Theoretically, there will be mixed enzymes produced by microbes, containing more than one (1) enzyme, and it will be very depending on kinds of substrate and microbes which is cultivated. So far, no information on the enzymes secreted by chitinolytic bacteria, therefore, in this study, it will be reported all extracellular enzymes secreted by KLU 11.16 when cultivated in chitin medium. All enzymes secreted by the bacteria was identified using zymographic technique. However, characterization was only conducted on the targeted enzymes, which was chitosanase.

\section{MATERIALAND METHODS}

\section{Materials}

Isolate KLU 11.16 was refreshed from gliserol stock culture resulted from previous experiment. Colloidal chitin was made according to Trudel \& Asselin (1989). All chemicals and microbiological media used were of analytical grade.

\section{Growth Curve of KLU 11.16 and Enzyme Production Profile}

Growth curve was assessed by inoculating 1 loopfull of bacteria in Luria Bertani broth medium according to Stephenson (2003) with modification of using MSM medium containing $0.5 \%$ colloidal chitin 
to grow the bacteria. As a control, 1 batch of similar experiment using the same media but without bacteria was prepared. Sampling was conducted every 3 hours to obtain growth curve and profile of enzyme production.

\section{Production and Extraction of Enzyme}

Bacterial cells were cultivated following Chasanah et al. (2011). Crude chitosanase enzyme was obtained by centrifuging the resulting culture at $9.000 \times g\left(4^{\circ} \mathrm{C}\right.$, $25 \mathrm{~min})$. The crude enzyme was then concentrated using ammonium sulphate precipitation technique (Bollag \& Edelstain, 1991). The precipitate obtained was suspended in $15 \mathrm{ml} 0.05 \mathrm{M}$ phosphate buffer $(\mathrm{pH}$ 7.0) followed by salt removal by dialysis process using the same buffer.

\section{Assay of Chitosanase Activity}

Assay of chitosanase activity was done based on the method described by Yoon et al. (2000) with modification as in Chasanah et al. (2011). The enzyme activity was presented as $\mathrm{U} / \mathrm{mL}$ enzyme volume or $\mathrm{U} /$ $\mathrm{mg}$ protein for specific activity. One unit of chitosanase activity was defined as the amount of enzyme that produce reducing sugar corresponds to $1 \mathrm{mmol}$ of $D$ glucosamine per minute.

\section{Measurement of Protein Content}

The protein content of the crude enzyme was estimated according to the Lowry method with bovine serum albumin as the standard (Bollag \& Edelstain, 1991).

\section{Determination of Optimum $\mathrm{pH}$ and Tempera- ture}

The optimum $\mathrm{pH}$ of chitosanase activities was determined at $37^{\circ} \mathrm{C}$ by using overlapping $\mathrm{pH}$ ranges. The buffer used were $0.2 \mathrm{M}$ citrate buffer $(\mathrm{pH} 4.0-6.0)$, $0.2 \mathrm{M}$ phosphate buffer ( $\mathrm{pH} 6.0-8.0$ ), $0.2 \mathrm{M}$ borate buffer (pH 8.0-9.0), 0.2 M glycine buffer ( $\mathrm{pH}$ 9.0-10), $0.2 \mathrm{M} \mathrm{NaOH}$-borate buffer (pH 10). The optimum temperature of the enzyme was measured at different temperatures $\left(30,37,50,60,70^{\circ} \mathrm{C}\right)$ at optimum $\mathrm{pH}$. The measurement procedure and conditions followed the standard assay as described previously.

\section{Thermostability Study}

Enzyme thermostability was determined as follows. An enzyme solution was firstly distributed into tightly closed eppendorf tube, in which each vial contained $50 \mu$ l enzyme. Then the tubes were incubated at a desired temperature in the water bath. Every 15 minutes, one of the tubes was withdrawn and immediately cooled on ice for a short time. The remain enzyme activity was assayed at the optimum temperature using the standard assay as described before. The enzyme activity was presented as \% relative activity in which the enzyme activity of control $(\mathrm{U} / \mathrm{mL}$ or $\mathrm{U} / \mathrm{mg})$ is considered as $100 \%$ activity. The enzyme activity (\% relative activity) was calculated as $=$ (enzyme activity of the sample treatment/ enzyme activity of the control) $\times 100 \%$

\section{Effect of Metals}

The effects of cations $\mathrm{Mg}^{2+}, \mathrm{Mn}^{2+}, \mathrm{Co}^{2+}, \mathrm{Zn}^{2+}, \mathrm{Ca}^{2+}$, $\left.\mathrm{K}^{+}, \mathrm{Fe}^{2+}\right)$ as chlorides metals were measured at the final concentration of $1 \mathrm{mM}$ of the metal ion in the enzyme mixture as Chasanah et al. (2011). The enzyme activity was presented as $\%$ relative activity as mention above, in which $100 \%$ activity was from the activity of control treatment or without addition of metal ion.

\section{SDS-PAGE and Detection of the Enzyme by Zymogram}

SDS-PAGE and zymogram were performed in $10 \%$ $(w / v)$ polyacrylamide gel. The substrates used for zymogram were $0.1 \%(\mathrm{w} / \mathrm{v})$ of $85 \%$ and $100 \%$ DA soluble chitosan, glycol chitin, casein, gelatin, CMC, and soluble starch for chitinolytic, proteolytic and carbohydrate degrading enzymes, respectively samples were running without boiling with gliserol and $2.5 \%$ SDS in $125 \mathrm{mM}$ Tris- $\mathrm{HCl}(\mathrm{pH} \mathrm{6.7)}$. Electrophoresis was run at constant current of 50 and $25 \mathrm{~mA}, 100$ volt at $4^{\circ} \mathrm{C}$. After separation, the gel was renatured by following Chasanah (2006) for chitinolytic enzymes, and Choi et al. (2006) for the proteases.

\section{RESULTS AND DISCUSSION}

KLU 11.16 was Gram negative, rod (bacilli) bacteria (Figure 1). The bacteria had lag phase up to 3 hours growth (Figure 2), and logarithmic phase was achieved after about 6-30 h cultivation. Stationary phase occurred after $30 \mathrm{~h}$ cultivation.

When cultivated at MSM medium enriched with $0.5 \%$ of colloidal chitin at room temperature, $100 \mathrm{rpm}$ shaker bath and harvested at 48 hours, KLU 11.16 produced not only chitinolytic enzymes but also other enzymes such as proteolytic and cellulolytic enzyme as they degraded casein, CMC and starch (Figure 4 and 5). Harvest time of 48 hours was used since our targeted enzyme, i.e chitosanase was produced maximally at that time (Figure 3 ). Figure 4 shows SDS-PAGE and zymogram analysis of the crude extract showing about 14 proteins bands. It had been extracellular produced and secreted in the medium, and among them, there were chitin, starch, and casein 

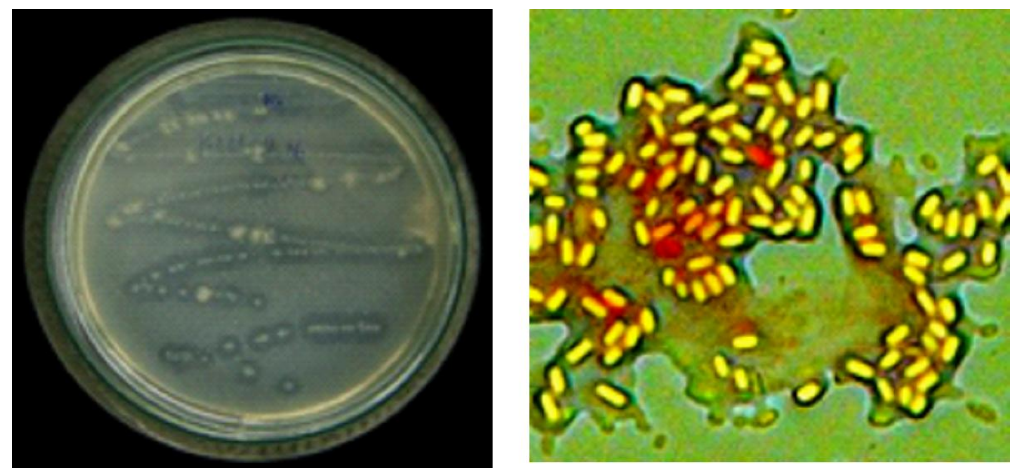

Figure 1. KLU 11.16 isolate (LAJ:KLU 11.16 colonies on solid MSM; LBJ:morphology of the isolate at $2000 \mathrm{x}$ )

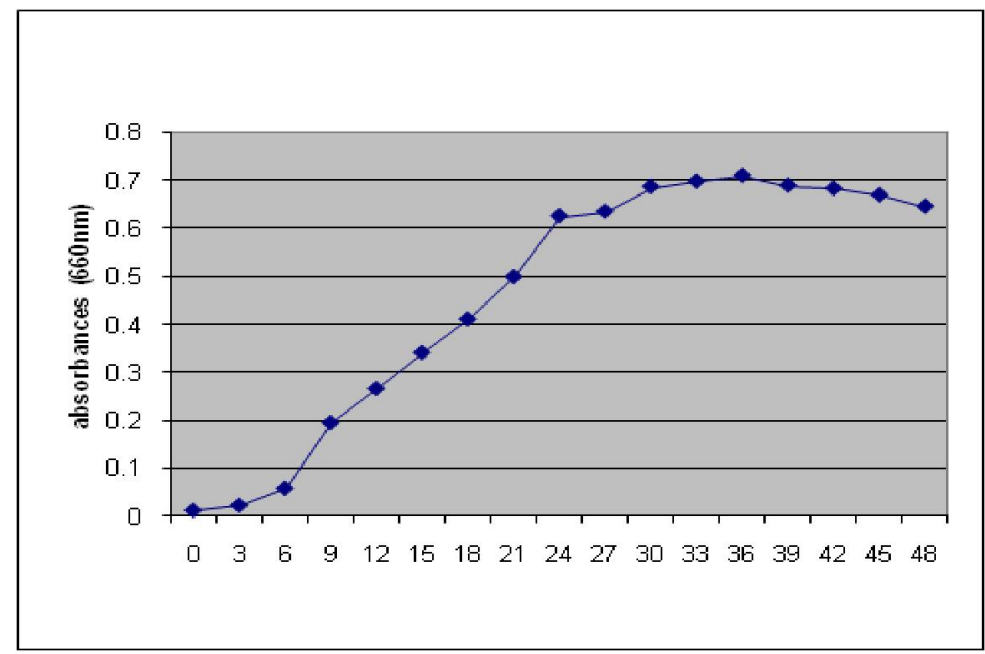

Figure 2. Growth curve of KLU 11.16.

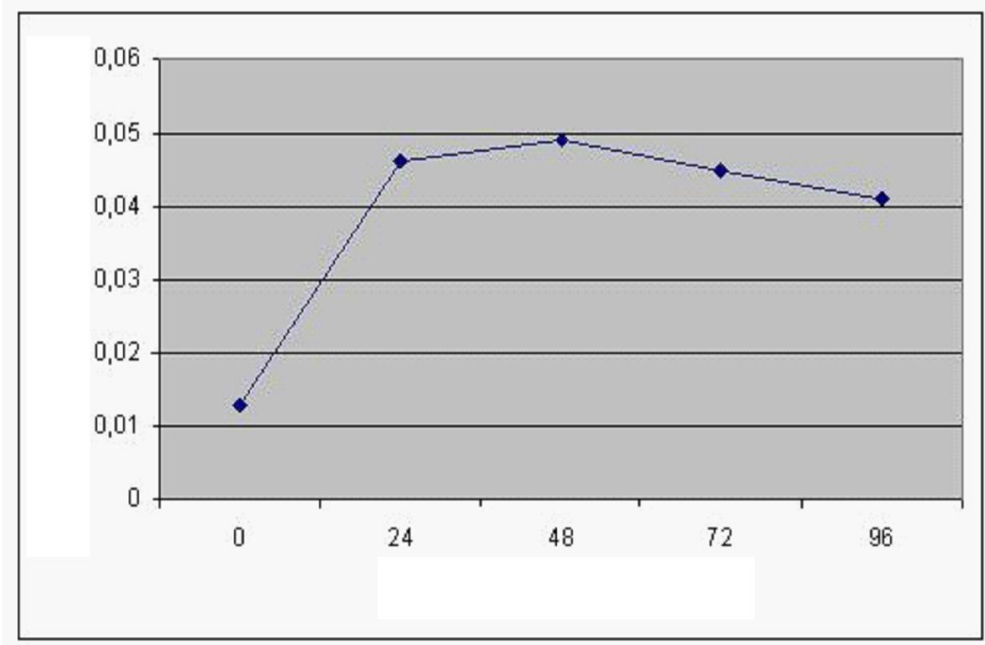

Figure 3. Production of crude enzyme by KLU 11.16 which was cultivated in chitin medium.

degrading enzymes. The molecular weight of the protein bands were predicted around $14.9 \mathrm{kDa}, 16.4$ $\mathrm{kDa}, 17.5 \mathrm{kDa}, 19.2 \mathrm{kDa}, 21.0 \mathrm{kDa}, 25.3 \mathrm{kDa} 28.6$ $\mathrm{kDa} 31.4 \mathrm{kDa} 34.5 \mathrm{kDa} 37.8 \mathrm{kDa} 40.2 \mathrm{kDa} 42.7 \mathrm{kDa}$ $67.9 \mathrm{kDa}$ and $98.3 \mathrm{kDa}$. Chitosanase was predicted to have molecular weight of about $98 \mathrm{kDa}$, while $\mathrm{CMC}$ and soluble strach degrading enzyme were detected at around $30.5 \mathrm{kDa}$ and $26.5 \mathrm{kDa}$, respectively. The bacteria secreted casein degrading enzyme having molecular weight at around $46.7 \mathrm{kDa}$, collagen degrading enzyme with molecular weight of around $22.5 \mathrm{kDa}$, but no gelatin degrading enzyme secreted. 
The implication of these non chitinolytic enzymes detected in crude enzyme secreted by KLU 11.16 was related to the application of the crude enzyme as biological agent to produce chitooligosachharide or chitosan oligomer. Using crude enzyme has advantages over the pure enzyme in which more simple and low production cost. However, the presence of non chitinolytic enzymes will affect hydrolysis, which will be more complex and not specific. Therefore, in the application of a crude enzyme, information on the non targeted enzyme will be valuable to set application strategy of using the crude enzyme in the processing of chitooligosaccharide.

Figure 5 showed that the crude enzyme degraded $85 \%$ DA chitosan better than $100 \%$ DA chitosan. It means that this crude enzyme might contains all 3 classes of chitosanases which are 1) capable of hydrolysing $\beta$ 1-4 linkage bonds between glucosamine (GlcN)-N acetyl glucosamine (GlcNAc) bond and
GlcN-GlcN bond and 2) capable of hydrolysing only GlcNAc-GlcN bond, and 3) capable of hydrolysing GlcNAc-GlcN as well as $\mathrm{GlcN}-\mathrm{GlcN}$ bond. The crude enzyme also contain chitinase enzyme which is capable of hydrolysing GIcNAc - GIcNAc bonds which is presence in glycol chitin as shown at Figure 5. From this result, the application of the crude enzyme will be less effective when using $100 \%$ DA chitosan which will have more functional groups in the chitosan derivatives product.

Crude chitosanases produced by KLU 11.16 performed well at pH 6 (Figure 6) and temperature of $30^{\circ} \mathrm{C}$ (Figure 7). At the optimum $\mathrm{pH}$, the chitosanases activity was $0.37 \mathrm{U} / \mathrm{mL}$ or $37 \mathrm{U} / \mathrm{L}$.

The presence of $1 \mathrm{mM}$ trivalent $\mathrm{Fe}^{+}$ion as $\mathrm{Cl}_{2}$ salt increased the chitosanases activity by $118 \%$, while $\mathrm{Zn}^{2+}, \mathrm{Mn}^{2+}, \mathrm{Co}^{2+}$, and monovalent ion $\mathrm{K}^{+}$ decreased the activity. These results were in accordance with the properties of Bacillus sp KCTC

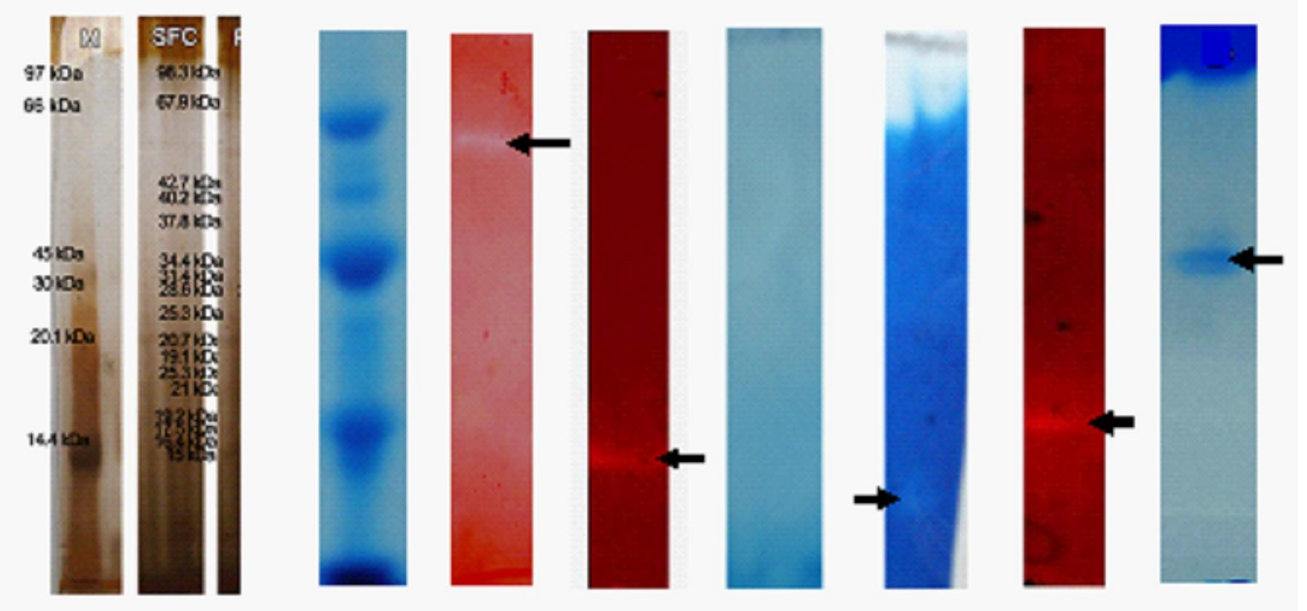

Figure 4. SDS PAGE and zymogram of extracellular enzyme secreted by KLU 11.16 (Note: $\mathrm{M}=$ marker $\mathrm{LMW}, \mathrm{A}=$ soluble chitosan, $\mathrm{B}=\mathrm{CMC}, \mathrm{C}=$ gelatin, $\mathrm{D}=$ colagen, $\mathrm{E}=$ soluble strach, $\mathrm{F}=$ casein).

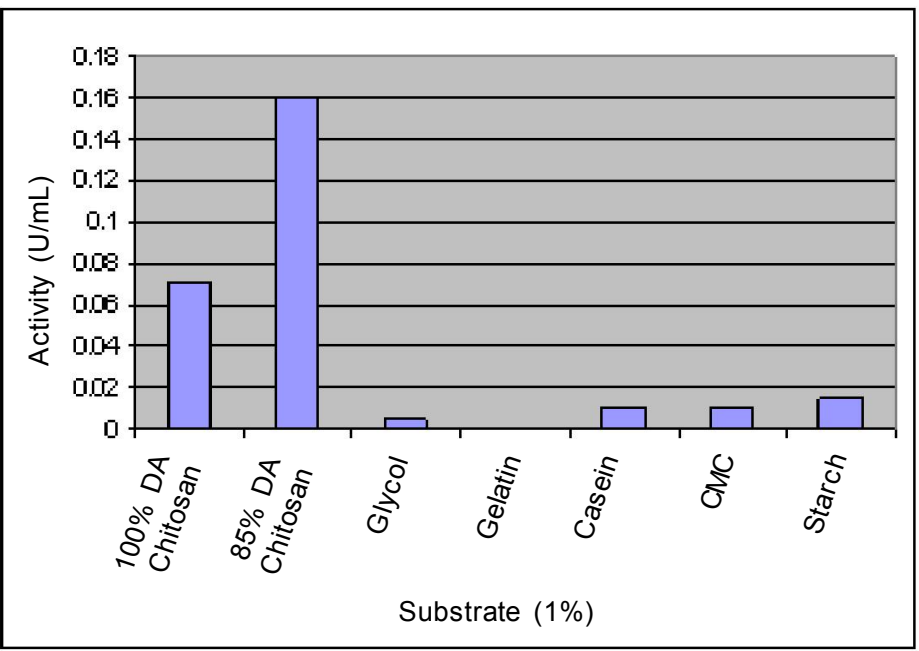

Figure 5. Extracellular enzymes secreted by KLU 11.16. 


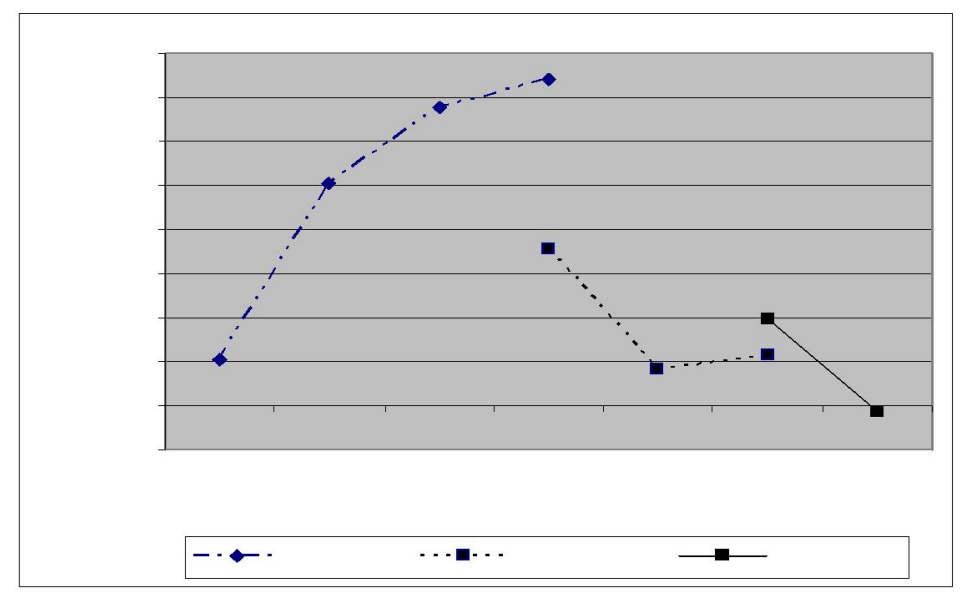

Figure 6. Optimum pH of KLU 11.16 chitosanase.

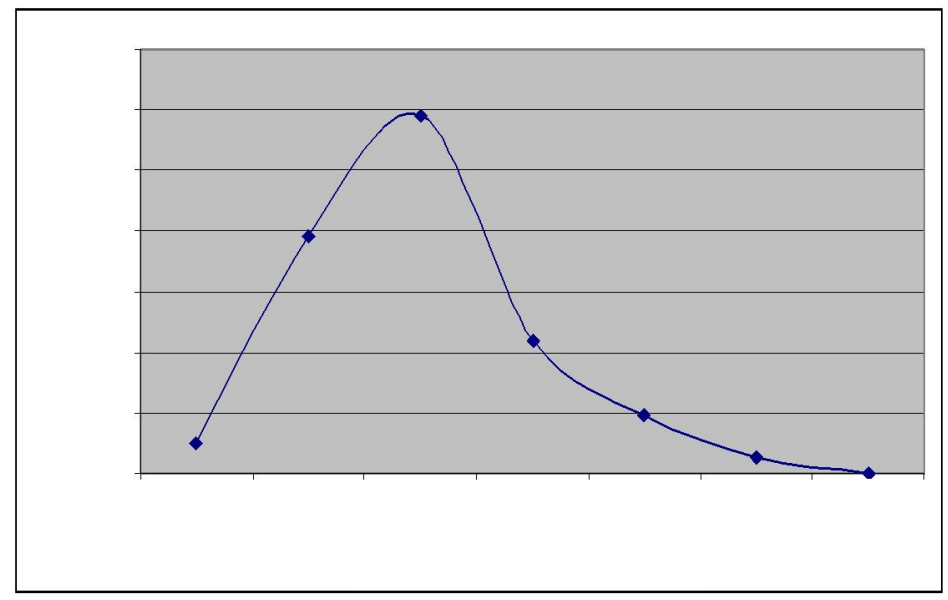

Figure 7. Optimum temperature of KLU 11.16 chitosanase.

0377BP chitosanases which were decreased by $\mathrm{Mn}^{2+}$ ion to $69 \%$ (Choi et al, 2004). However, previous result showed that $\mathrm{Mn}^{2+}$ along with $\mathrm{Co}^{2+}, \mathrm{Ca}^{2+}, \mathrm{Mg}^{2+}$ were able to increase the chitosanase activity, while $\mathrm{Zn}^{2+}$ decreased the activity of chitosanases produced by Bacillus licheniformis MB-2 (Chasanah et al., 2006). Park et al. (1999) reported that chitosanases from soil bacteria Matsubacter chitosanobidus 3001 was inhibited by $\mathrm{Ag}^{2+}$ while the presence of $\mathrm{Ba}^{2+}, \mathrm{Ca}^{2+}$, $\mathrm{CO}^{2+}, \mathrm{Hg}^{2+}, \mathrm{Cu}^{2+}, \mathrm{Mg}^{2+}, \mathrm{Fe}^{2+}, \mathrm{Mn}^{2+}$ and $\mathrm{Zn}^{2+}$ did not affect the enzyme activity. Meanwhile chitosanases from fungus Aspergillus was inhibited by $\mathrm{Hg}^{2+}$ dan $\mathrm{Cd}^{2+}$ and increased by the presence of $\mathrm{Mn}^{2+}$ dan $\mathrm{Cu}^{2+}$ (Cheng \& Yaw, 2000). The effect of ion metal to the enzyme activity can be detrimental or can be advantegous depending on the ion metal function to the three dimensional structure and catalytic site of the enzyme. Ion metal can strengthen the three dimensional structure of the enzyme by optimizing charge-charge interaction and regaining number of hydrogen bond. Ion metal could also stabilize enzyme's conformation by locking the active site
(Voght et. al., 1997; Veille et al., 2001), or to obtain local charge balance of the catalytic site. Metal ions, in general, takes a function as part of the enzyme catalytic mechanism and or stabilizer of the active site of protein enzyme. When participating in the catalytic mechanism, metal cation can bring specific functional group together in the appropriate orientation for reaction.

The presence of $\mathrm{Na}^{2+}$ and $\mathrm{Ca}^{2+}$ in this study did not affect the activity of the chitosanase in crude enzyme (Figure 8), i.e the addition of those divalent ion in the final concentration of $1 \mathrm{mM}$ could not increase or decrease the activity. It means that those ion might strengthen and stabilize the three dimensional structure of the KLU 11.16 chitosanase, while other ions, namely $\mathrm{Zn}^{2+}, \mathrm{Mn}^{2+}, \mathrm{Co}^{2+}$ and monovalent ion $\mathrm{K}^{+}$ might disturb the three dimensional structure of the enzyme, consequently the presence of those ions decreased the enzyme activity. The presence of impurities in a crude enzyme could also participate in the complexity of the function of ion metal in this study. 


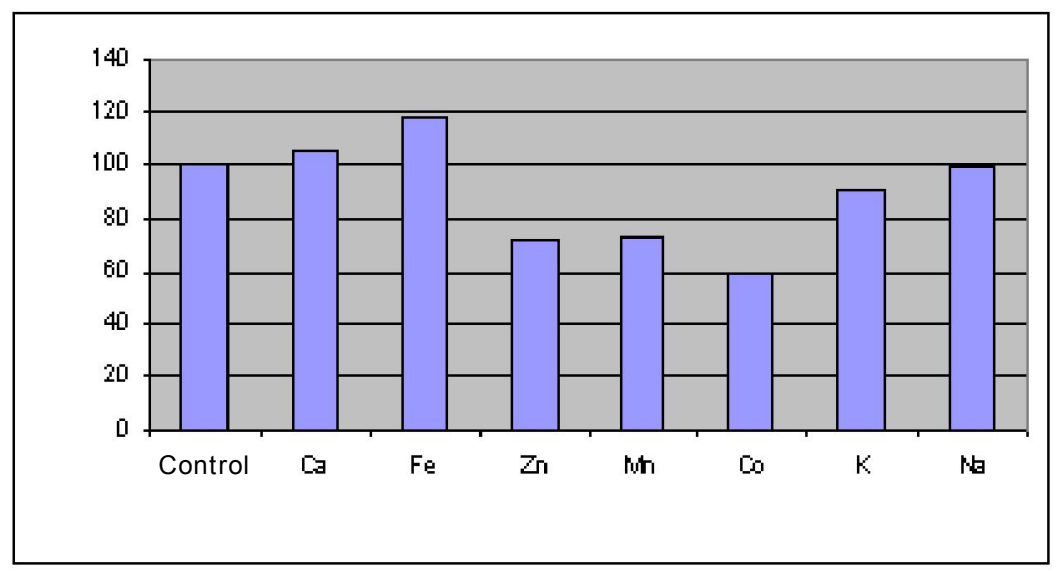

Figure 8. Effect of metal ion as $\mathrm{Cl}_{2}$ salt to the enzyme activity; control, as treatment without addition of divalent and monovalent ions, was calculated as $100 \%$ activity.

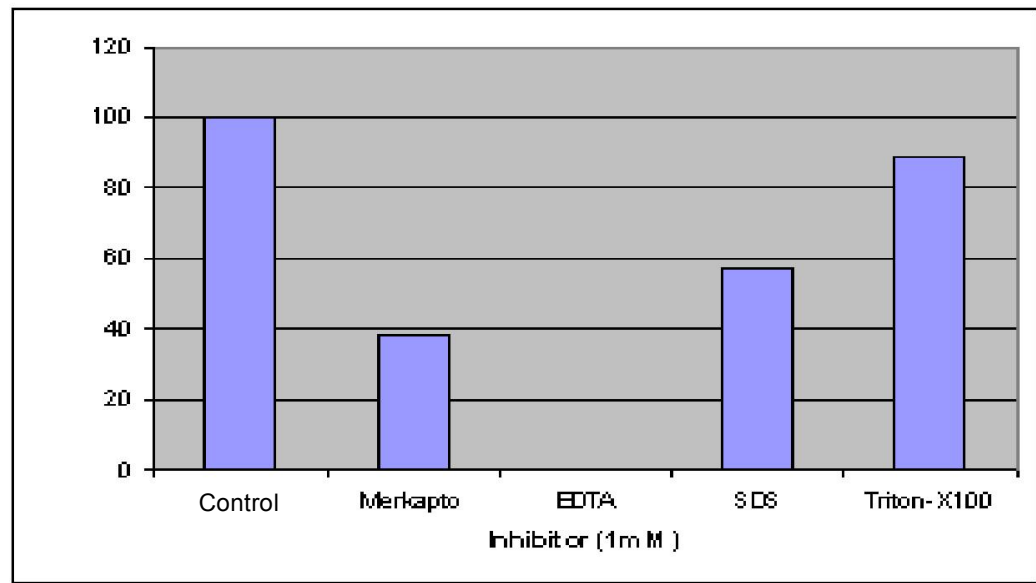

Figure 9. Addition of additives.

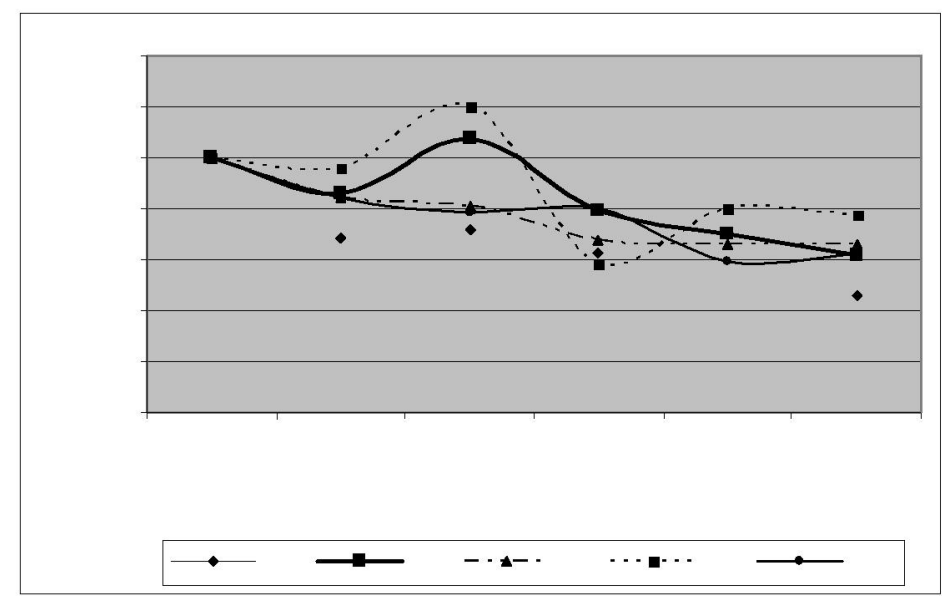

Figure 10 . Heat stability of KLU 11.16 chitosanase.

Effect of additives, i.e ß-merkaptoetanol, EDTA, SDS dan Triton $X-100$ to the enzyme activity can be shown at Figure 9. ß-merkaptoetanol (reducing agent), SDS and Triton X-100 (detergent) are commonly used during SDS-PAGE and other steps of enzyme characterization such as purification. EDTA is chelating agent widely used to treat cellophan for dialysis process and ingredient of renaturation buffer of 
zymogram analysis. The four (4) additives showed to decrease the enzyme relative activity amounting to $38 \%, 0 \%, 57 \%$, and $89 \%$ for ß-merkaptoetanol, EDTA, SDS dan Triton X-100 respectively.

Figure 10 shows heat stability of the enzyme. Activity of the enzyme was reduced $50 \%$ after treated at $60^{\circ} \mathrm{C}$ for 150 minutes. Other treatments (incubation at $25,30,37,50^{\circ} \mathrm{C}$ ) were relatively stabilize the enzyme activity up to 150 minutes.

\section{CONCLUSION}

When cultivating in chitin medium, KLU 11.16 secreted 14 proteins. Among them were chitosanases enzyme which was predicted to have molecular weight of about $98 \mathrm{kDa}, \mathrm{CMC}$ and soluble starch degrading enzyme which was detected at around $30.5 \mathrm{kDa}$ and $26.5 \mathrm{kDa}$, respectively. The bacteria secreted casein degrading enzyme having molecular weight at around $46.7 \mathrm{kDa}$, and collagen degrading enzyme having molecular weight at around $22.5 \mathrm{kDa}$.

Chitosanase secreted in the crude enzyme was performed well at $\mathrm{pH} 6$ and temperature of $30^{\circ} \mathrm{C}$, and the activity can be increased by addition of $1 \mathrm{mM}$ $\mathrm{Fe}^{3+}$ in form of chloride salt. Addition of detergent, i.e $1 \mathrm{mM}$ of Triton X-100 and SDS slightly decreased its activity. This enzyme digested $85 \%$ DA better than $100 \%$ DA chitosan.

\section{REFERENCES}

Bollag, D.M. and S.J. Edelstein. 1991. Protein Methods. Wiley-Liss a John Wiley \& Sons, Inc., New York.

Charles-Rodriguez A.V., Mauricio-Benavides J.E., GarzaGarcia, Y., Aguilar, C.N., Rodriguez, J., and ContreasEsquivel, J.C. 2008. Chitosanases production by a new bacterial sources. Res J. of Biol Sci. 3 (8): 957963.

Chasanah, E., Gintung, P., Zilda, D.S., Ali, M., and Risjani, Y. 2011. Purification and characterization of Aeromonas media KLU 11.16 chitosanase isolated from shrimp waste. J. of Coastal Development. 15 (1): 104-114.

Chasanah, E., IImi, M., and Mangunwardoyo. 2009. Screening of chitinolytic bacteria from shrimp processing waste (in Indonesia). Jurnal Pasca panen dan Bioteknologi Kelautan dan Perikanan. 4 (1).

Chasanah, E., Hariyadi, P., Witarto, A.B., Hwang, J.K., and Suhartono, M.T. 2006. Biochemical Characteristics of Chitosanase from the Indonesian $B$. licheniformis MB-2. Journal of Molecular Biotechnology. 33 (2): 93-102.

Cheng, C.Y. and Yaw, L. 2000. An Aspergillus chitosanase with potential for large scale preparation og chitosan oligosaccharides. Biotechnol. Appl. Biochem. 32: 197-203.

Chien-Jui, H., Tang, K.W., Shu, C.C., and Chao, Y.C. 2005. Identification and antifungal chitinases from a potential biocontrol agent, Bacillus cereus. 28-9. J. of Biochem. and Mol. Biology. 38 (1): 82-88.

Choi, Y. J., Kim, E.J., Piao, Z., Yun, Y.C., and Shin, Y.C. 2004. Purification and characterization of chitosanase from Bacillus sp. strain KCTC 0377BP and its application for the production of chitosan oligosaccharides. Appl. Environ. Microbiol. 70(8): 4522-4531.

Fawzya, Y.N. and Wibowo, S. 2009. Exploration of Indonesia Marine Chitinolytic Enzymes and their application. Indonesian Marine and Fisheries Product Processing and Biotechnology. Research Center for Marine and Fisheries Product Processing and Biotechnology. Jakarta.

Fukamizo and Brezinski, 1997. Chitosanase from streptomyces sp strain N174: a comparative review of its structure and function. Biochem Cell Biol. 75: 687-689.

Noviendri, D., Fawzya, Y.N., and Chasanah, E. 2006. Characterization and kinetics of chitinase produced by T5a1 bacteria isolated from terasi (in Indonesian). J. Penelitian Pengolahan Produk dan Bioteknologi Kelautan dan Perikanan. 4 (2).

Park, J.K., Shimino, K., Ochiai, N., Shigeru, K., Kurita, M., Ohta, Tanaka, K., Matsuda, H., and Kawamukai, M. 1999. Purification, characterization and gene analysis of chitosanases (Cho A) from Matsuebacter chitosanotabidus 3001 . J. of Bacteriol. Nov.: 66426649.

Patil, R.S., Ghormade V., and Deshpande, M.V. 2000. Chitinolytic enzymes: an exploration. Enzyme Microbiol. Technol. 26: 473-483.

Stephenson, F.H. 2003. Calculation for molecular and biology biotechnology. Academic Press, New York.

Tremblay, H., Yamaguchi, T., Fukamizo, T., and Brezinski, R. 2001. Mechanism of chitosanase oligosaccharide interaction: subsite structure of Streptomyces sp. N 174 and the role of asp 57 carboxylate. J. Biochem. 130: 679-686.

Trudel, J. and Asselin, A.1989. Detection of chitinases after polyacrilamide gel electrophoresis. Analytical Biochemistry. 178: 302-306.

Uria, A.R. and Chasanah, E. 2005. Chitinase and Chitosanase from Microorganism Associated with Marine Sponges. The $9^{\text {th }}$ of ASEAN Food Conference Proceeding.

Veille, C. and Zeikus, G.J. 2001. Hyperthermophylic enzyme; sources, uses and molecular mechanism of thermostability. Microbiol and Molecular Biol. Rev. 65 (1): 1-43.

Voght, G., Woell, S., and Argos, p. 1997. Protein thermal stability, hydrogen bonds and ion-pairs. J. Mol. Biol. 269: 631-643.

Yoon, H.G., Kim, Y.H., Lim, H.K., Kim, D.H, Shin, B.S., Hong, and Cho, H.Y. 2000. Identification of essential amino acid residue for catalytic and thermostability of novel chitosanases by site-directed mutagenesis. Applied Microbiol. Biotecnol. 56: 173-180.

Zilda, D.S., Fawzia, Y.N., and Chasanah, E. 2006. Chitosanase isolate T5a2 from terasi: Production and characterization. Jurnal Perikanan Indonesia. 2 (2). 